\title{
Distribution and patterns of spread of recolonising Eurasian beavers (Castor fiber Linnaeus 1758) in fragmented habitat, Agdenes peninsula,
} Norway

\author{
Duncan J. Halley', Ivonne Teurlings', Hannah Welsh' and Claire Taylor'
}

Halley DJ, Teurlings I, Welsh H and Taylor C. 2013. Distribution and patterns of spread of recolonising Eurasian beavers (Castor fiber Linnaeus 1758) in fragmented habitat, Agdenes peninsula, Norway. Fauna norvegica 32: 1-12.

The Agdenes peninsula, Sør-Trøndelag, Norway, $1060 \mathrm{~km}^{2}$, is a heavily dissected mountainous landscape with numerous small watersheds, of mainly steep gradient, flowing separately into the sea or to fjords. Suitable habitat for permanent beaver occupation occurs mainly as isolated patches within these watersheds. Eurasian beavers were directly reintroduced to the area in 1926 and 1928. The last known individual of this population died in 1961. In 1968-69 2 pairs and a young animal were reintroduced on the Ingdalselva watershed. The current population is descended from these animals, and probably from the later 1990s by immigrants from the adjacent Orkla river system. In 2010-11 the area was surveyed and 24 beaver family group home ranges located, 20 of which were currently active and 4 abandoned; the population size was estimated at about 80 individuals within family territories plus in any year a number of dispersing individuals. Eighteen of the active territories were located on just four watersheds, Ingdalselva and three immediately adjacent to it. The remaining two territories were isolated on different watersheds distant from any other known group, requiring multiple crossings between watersheds and/or considerable movements through salt water to reach from them. Signs of vagrant individuals were found widely, including on a number of watersheds not occupied by any family group, though containing suitable habitat for permanent colonisation. Known data on the date of establishment of each family group is given, and the pattern of recolonisation to date discussed. An isolated population of beavers on a section of the Orkla river system, first noted in 1933, has been attributed to spread from the first study area reintroductions. However, there are grounds to suspect that this population may have had a different origin. Genetic studies would be useful to elucidate this point.

doi: 10.5324/fn.v31i0.1438. Received: 2012-02-06. Accepted: 2012-05-14.

Published on paper and online: 2013-02-13.

Keywords: beaver, Castor fiber, distribution, reintroduction, dispersal

1. Norwegian Institute for Nature Research, Postboks 5685 Sluppen, NO-7485 Trondheim, Norway

Corresponding author: Duncan Halley

E-mail: duncan.halley@nina.no

\section{INTRODUCTION}

Patterns of spread and population development in beavers have mainly been studied at the scale of large watersheds, and/or in areas where beaver habitat is relatively continuous and groups of territories lie contiguous to each other (e.g. Hartman 1994,
1996; Fustec et al. 2001; Elmeros et al. 2003; Berthelsen 2008; John et al. 2010; Sjöberg \& Ball 2011). These studies indicate an overall pattern of rapid spread within a watershed and much more restricted spread between watersheds (Halley \& Rosell 2002 for review). However, there is much less information 
available on patterns of spread in more fragmented habitat, where areas suitable for beaver territories within a watershed occur as isolated pockets separated by large stretches of unsuitable habitat, and where there are many small watersheds in strongly dissected, mountainous landscapes.

Such areas are of interest as an example of a system where the pattern of movements of dispersing individuals (and of local extinction events) may be particularly important in influencing the realized distribution of the species. They are also of interest with respect to species management, as a model for patterns of colonization in areas of similar topography and hydrology. Such areas include much of western Norway, and northern and western Great Britain (where a trial reintroduction is underway in western Scotland (http://www.scottishbeavers.org.uk/), and a population has become established on the largest watershed (Tay) apparently as a result of escapes (Halley 2011).

In this paper we present a study of beaver distribution in an area of active beaver colonisation, the Agdenes peninsula in Sør-Trøndelag, Norway (Figure 1); along with evidence of non-resident beaver movements in the area. The pattern of distribution is interesting in itself, and is intended to provide a baseline to be compared with developments in population and distribution over time. The history of beavers in the study area is reviewed from the information available.

\section{MATERIAL AND METHODS}

The study area (Figures 1,2,4) consists of all watersheds on the Agdenes peninsula in Sør-Trøndelag province, central Norway, excluding the watershed of the Orkla river system, which bounds the area to the south. This area includes all of mainland Snillfjord and Agdenes kommunes (local government districts), and those parts of Orkdal kommune which are not drained by the major Orkla river system, an area of approximately $1060 \mathrm{~km}^{2}$. The underlying geology is schists, gneisses and granites of the Caledonian orogeny. Terrain is steeply hilly; elevations range from sea level to $847 \mathrm{~m}$. Drainage is via many small watersheds draining separately into fjords or the sea and usually divided from each other by steep ridges, but with low-gradient cols between them in places (as a result of previous glacial action). Rivers and streams are mainly well over $2 \%$ in average gradient, the gradient above which beavers rarely establish territories (Slough \& Sadleir 1977; Howard \& Larson 1985; Beier \& Barrett 1987; Zurowski 1992; Rosell \& Pedersen 1999; Hartman \& Törnlöv 2006; Nyssen et al. 2011), with frequent cataracts and waterfalls. Coasts and fjord sides are in most places very steep or precipitous. Sites suitable for colonisation generally occur as isolated patches with sufficient habitat for only a single territory. The vegetation is southern boreal at sea level, sequencing with altitude through middle and northern boreal to alpine on higher peaks. The area is heavily wooded, mainly Scots pine Pinus sylvestris Linnaeus, 1753; Norway spruce Picea abies Karsten, 1881; and birch

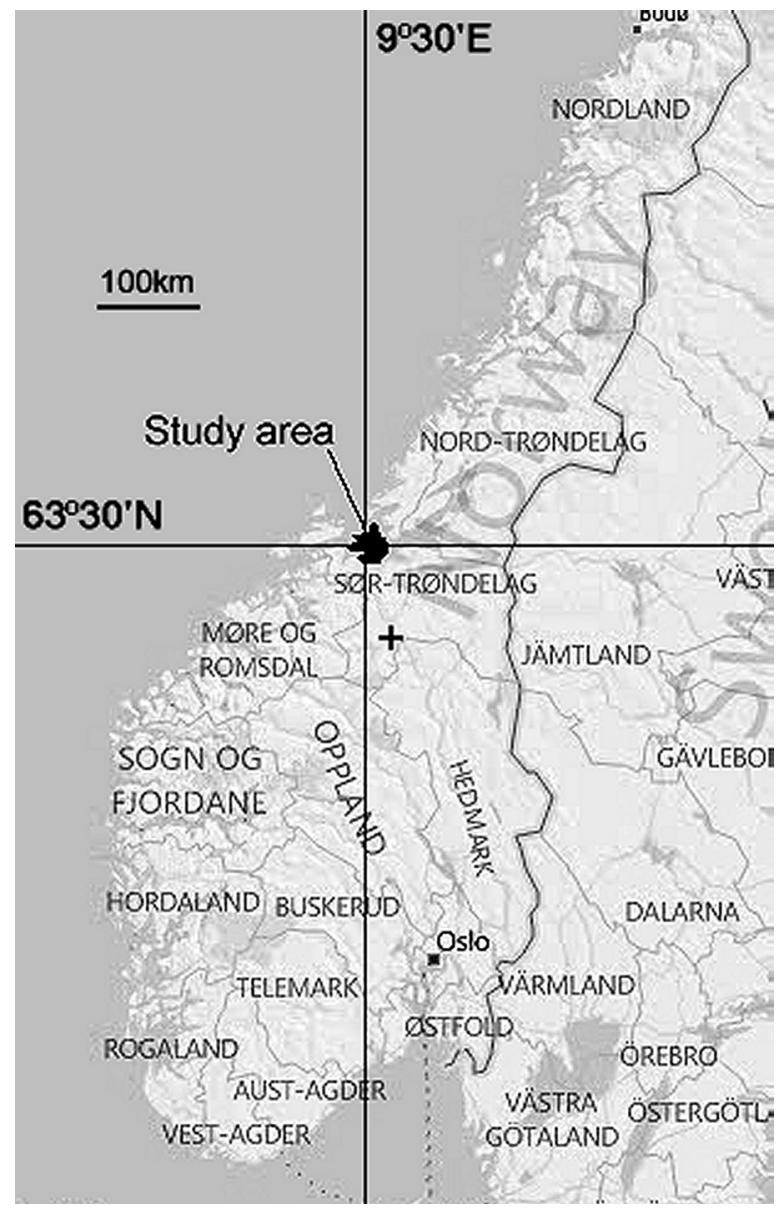

Figure I. Study area (black) in relation to southern and central Norway. The location of the Ulsberg-Voll section of the Orkla river is indicated by a cross.

Betula spp:; but with rowan Sorbus aucuparia Linnaeus, 1753; bird cherry Prunus padus Linnaeus, 1753; grey alder Alnus incana Linnaeus, 1753; willow Salix spp; and aspen Populus tremuloides Linnaeus, 1753 present in varying proportions.

The terrain is such that several of the main watercourses change name as they flow towards the sea, sometimes more than once, reflecting paths of, and barriers to, access for the human population in times past. In this article each watershed is referred to by the name it has where it reaches the sea. Terrain and vegetation can be examined in detail from maps and satellite imagery available at http://kart.statkart.no/adaptive2/ default.aspx?gui=1\&lang=1.

Coppice regrowth of trees felled by beavers is vigorous, despite considerable populations of moose Alces alces Linnaeus, 1758; red deer Cervus elaphus Linnaeus, 1758, roe deer Capreolus capreolus Linnaeus, 1758; and in summer domestic sheep Ovis aries Linnaeus, 1758. The climate is oceanic. Summers are generally cool and moist; winters mildly cold with variable, but in most winters appreciable, snow cover. Most slow flowing sections of watercourses and all lakes freeze over for several months in winter. 


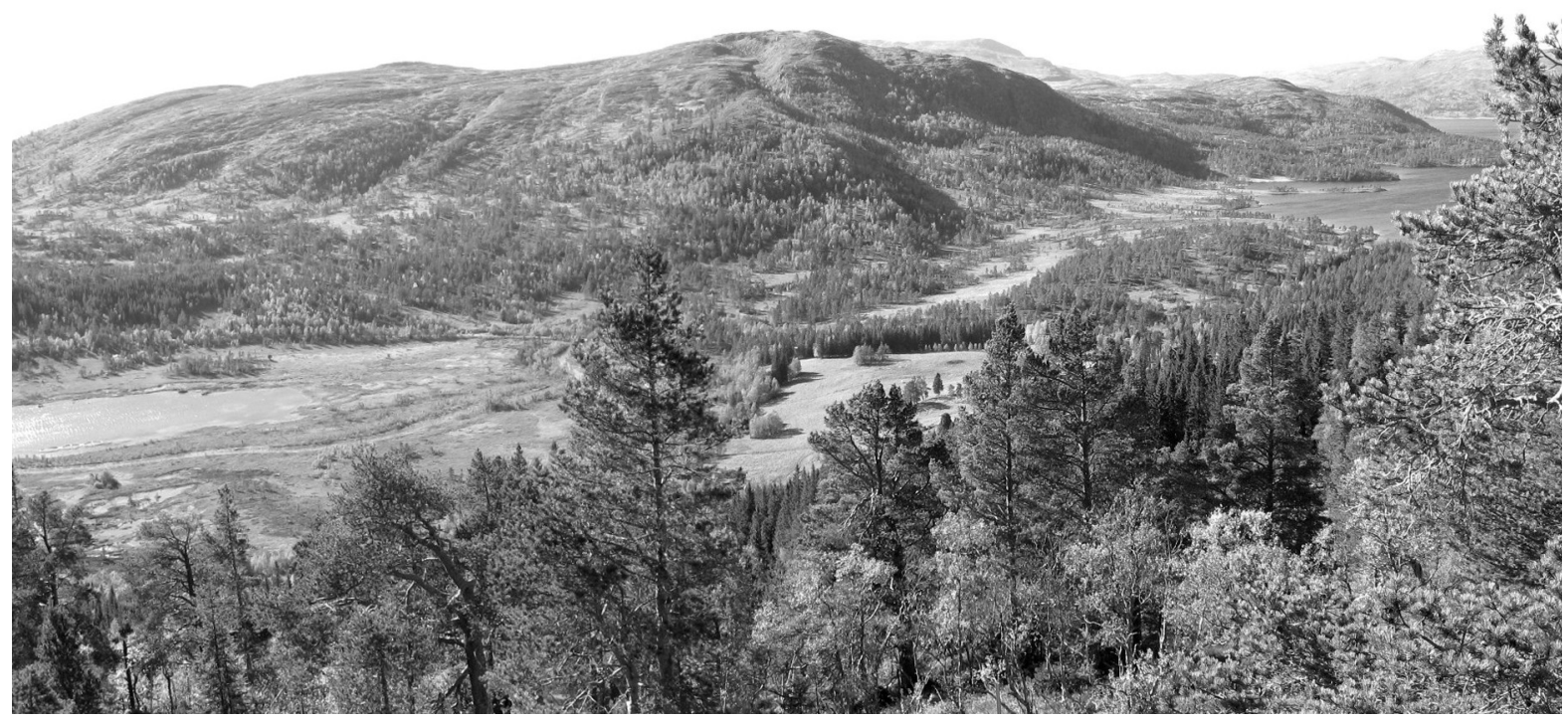

Figure 2. Part of the study area, showing typical landforms and vegetation. The river and bog at left are the site of beaver territory 10 (see Figure 4). Photo: D.J. Halley

Records of beaver occupation, and collection of historical materials on the population, were made by the first author from 1995 onwards. Although beavers are game animals in many areas of Norway, they have been a protected species in the study area (and on the lower Orkla) throughout the period from reintroduction onwards.

Systematic studies of current distribution were carried out in May-July of 2010 and 2011. All stream and riverbanks, and lake shores, in the field area not clearly unsuitable for sustaining settled beavers (above the tree line or very steep channel gradients, above ca. 4\%) were visited by the authors on foot and/or by canoe in each year, and checked for signs of beavers. Known territorial sites were also checked in the autumn of 2010-spring 2011 for signs of food stores and of recent activity. Occupation of a site was confirmed by the presence of beaver structures such as lodges or dams with signs of recent activity, e.g. mud plastering; by fresh tracks; trails in the snow; the assembling of food stores (autumn only); and/or the presence of recently cut stumps, twigs, and chewed sticks. Such activity was normally very obvious. Where there were no signs of recent maintenance of structures, or of any recent stumps, stripped twigs, food stores, etc. (some beavers in our study area live in burrows and most do not build dams (Table 1), so many territories do not have any visible beaver structures at all), the site was assumed to be inactive. Where we found only one or a few stumps or cut twigs remote from established territories these were taken to be evidence of vagrant individuals and not settled family groups. These could be divided into fresh signs, made since the spring of the year of monitoring, and older signs.

From the later 1990s beavers also established territories on stretches of the Orkla river system adjacent to the study area (Bonvik \& Rønning 2006; see below, Figure 4). There are no known beaver populations on the north and northeastern shore of Trondheimsfjord opposite the study area (the Fosen peninsula); on any of the offshore islands to the northwest; or in Hemne kommune or More \& Romsdal province, which lie to the west and southwest of the study area.

\section{RESULTS}

Historical records and many place names indicate the species was common and widespread throughout Trøndelag in historic times, including the study area (e.g. Bjørbekken, "beaver stream', Table 1). The original population is thought to have been exterminated by the early part of the $19^{\text {th }}$ century. The last animals in Sør-Trøndelag are said to have been trapped out by a

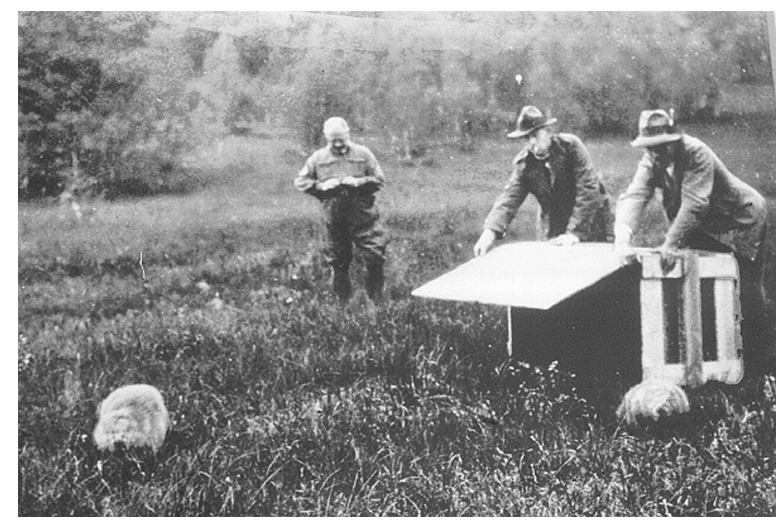

Figure 3. Release of beavers on the Songli property, 1926 or 1928. Photo from Songli Pictorial Archive; photographer unknown. 
"Swedish Lapp" in Selbu/Tydal about 1820-1830 (Collett 1898; Bevanger 1995).

A pair of beavers from "the fringes of Arendal (Arendalskanten)", southern Norway, were reintroduced to the large Songli property, which lies on the Skjenaldelva and Bergselva watersheds, in $1926^{1}$ (Sør-Trøndelag newspaper, 28 August 1926). The site of this release was in 1929 reported to have been in Grytdalen, ie upper Bergselva watershed near Melandsøya, current site 14 (Figure 4) (Sør-Trøndelag newspaper, 12 September 1929); however, in October 1926 a memorandum from C. Thams which has survived (Songli private records, J. Andøl pers. comm.) states "The beavers: we need to find out where the beavers are living, and if it is on Våvatnet (site B, Figure 4) the ice must be broken and necessary measures taken ... so they are not excluded from water". This clearly implies they were reintroduced at Amottjønna near Våvatnet (site A, Figure 4), as stated in Olstad (1937) and by E. Carlsen (in litt to K. Brox 7 October 1965); but had moved from the release site.

A further pair were reported to have been released in 1928 'by Songsjøen', the lake holding current site 9, (SørTrøndelag newspaper, 12 September 1929) probably again meaning Åmotstjønna.

It is probable that a further pair was also released in Grytdalen in 1928 (see above), as sources after this date repeatedly allude to a release also having been made there. E. Carlsen, who lived locally, states this was done (in litt. to K. Brox, 7 October 1965). Olstad (1937), however, states that all 6 animals were released at Åmottjønna.

In 1929 a beaver was seen on 3 consecutive evenings on Våvatnet ${ }^{2}$ (site B, figure 4) and a group of rowans felled at Vådåosen at the west end of the lake (letter in SørTrøndelag newspaper, 24 September 1929). The writer assumed they had come from 'the beavers which were released in Grytdalen'. Beavers were reportedly present at Våvatnet until 1938 (Lindsetmo 1974). Beaver-gnawed trees were also noted at Melås on Gagnåsvatnet (midway between current sites 5 \& 6, Figure 4) in September 1929 (Sør-Trøndelag newspaper, 12 September 1929). A probably vagrant individual was shot at

1. Published sources vary in the exact location(s), watershed(s), years, and numbers released (4 or 6) given for the 1920s releases though all agree that: the location was the Songli property in the Skjenaldelva and Bergselva watersheds, then owned by industrialist C. Thams and associates and - unusually for Norway - managed as a hunting estate; that releases were in two different years; and that one pair at least (and up to all three pairs) were released near Songli farm, most later sources naming Åmotstjønna, following Olstad (1937). The account here follows information in Songli archives, published sources by individuals with personal knowledge of the area and of the 1920s - 1961 population, accounts in local newspapers of the time, and other published sources in that order of priority.

2. Våvatnet is now regulated as the drinking water supply for Orkanger and shorelines are not suitable for colonisation
Hostonvatnet (site C, Figure 4) on the Vorma tributary of the Orkla "at the beginning of the 30s" (Pedersen 1967), apparently mistaken for an otter (E. Carlsen 1965, in litt to K. Brox).

Beavers bred at the Melandsøya site within two years of the initial release there (Møller 1967) and also established downstream at Auset in 1928 (current territory 16, Figure 4; Olstad 1937, who assumes spread from Åmottjønna), where they bred and were present "for many years" (Sør-Trøndelag newspaper, 25 April 1959) and noted as being very active in 1936-7 (Lund 1959). Melandsøya was occupied until 1942-43, abandonment of the site being attributed to heavy harvesting of deciduous trees by the then owners; and later beavers were noted at Austvatnet (site D, Figure 4) in the Lena watershed and at Rangvatnet (site E, Figure 4) and Butulsvatnet (site F, Figure 4), and lower Ingdalselva, all in the Ingdalselva watershed. A dead beaver was washed up at Ålmli in Orkdalsfjorden, $3 \mathrm{~km}$ NE of the mouth of the Skjenaldselva, in the 1930s (E. Carlsen 1965, in litt to K. Brox). Old beaver signs were found on an Orkla tributary at Svorkåsen, 3km ESE of current site 4, in the 1930s (Olstad 1937). A beaver was killed at Orkland near the Vorma-Orkla confluence 'about 1932' and one killed in a trap in Hemne kommune, SW of the study area, in 1932 (op. cit). This last animal probably dispersed down the fjord from Bergselva. The last known individual descended from this reintroduction died on the Ingdalselva watershed in spring 1961 at Snåkkåsdalbekken, the same location as the current site 13 (Figure 4) (K. Brox pers. comm.; Møller 1967; Pedersen 1967).

The present population originates from a new reintroduction to the area, planned from 1965 by Karl H. Brox and Emil M. Carlsen. A pair was obtained in 1968 and was released on the Ingdalselva watershed (which holds current territories 11 - 13) on $1^{\text {st }}$ September. The release was originally planned for Almlisletta (site G, Figure 4; K. Brox pers. comm.), a small marshy area at relatively high elevation (390m asl) in Husdal Statsallmenning (State common land), but in fact took place at Snåkkåsdalbekken (current territory 13, Figure 4: Møller 1967; Sør-Trøndelag newspaper, 3 September 1968; Carlsen 1972). By the following year they were present at Butulsvatnet (site F, Figure 4), a small lake at $180 \mathrm{~m}$ asl on a tributary of the Ingdalselva (E. Carlsen in litt to K. Brox, 1969) and had constructed a lodge (Adresseavisen 24 September 1969). A further pair and a young animal were reintroduced in 1969 , to the same site at Snåkkåsdalbekken, by Sør-Trøndelag Skogforvaltning (South Trøndelag Forest Authority) (Adresseavisen 24 September 1969; Carlsen 1972; Holgeir Oppdal pers comm). All 5 animals were obtained from Åmli, Aust-Agder, southern Norway. Breeding was confirmed in 1970, though the location was not specified (Møller 1970). By the end of 1973 beavers had occupied at least 4 sites on the Ingdalselva watershed (sites F, 11, 12, \& 13) and another at Bjørbekken on the Skjenaldelva watershed (site 2); the population was then estimated 'with certainty' to be at least

3. Myrberget (1977) states that the releases were at Songli, on the Skjenaldelva watershed near the current site 10 , and this is cited in several later sources; but is an error. 


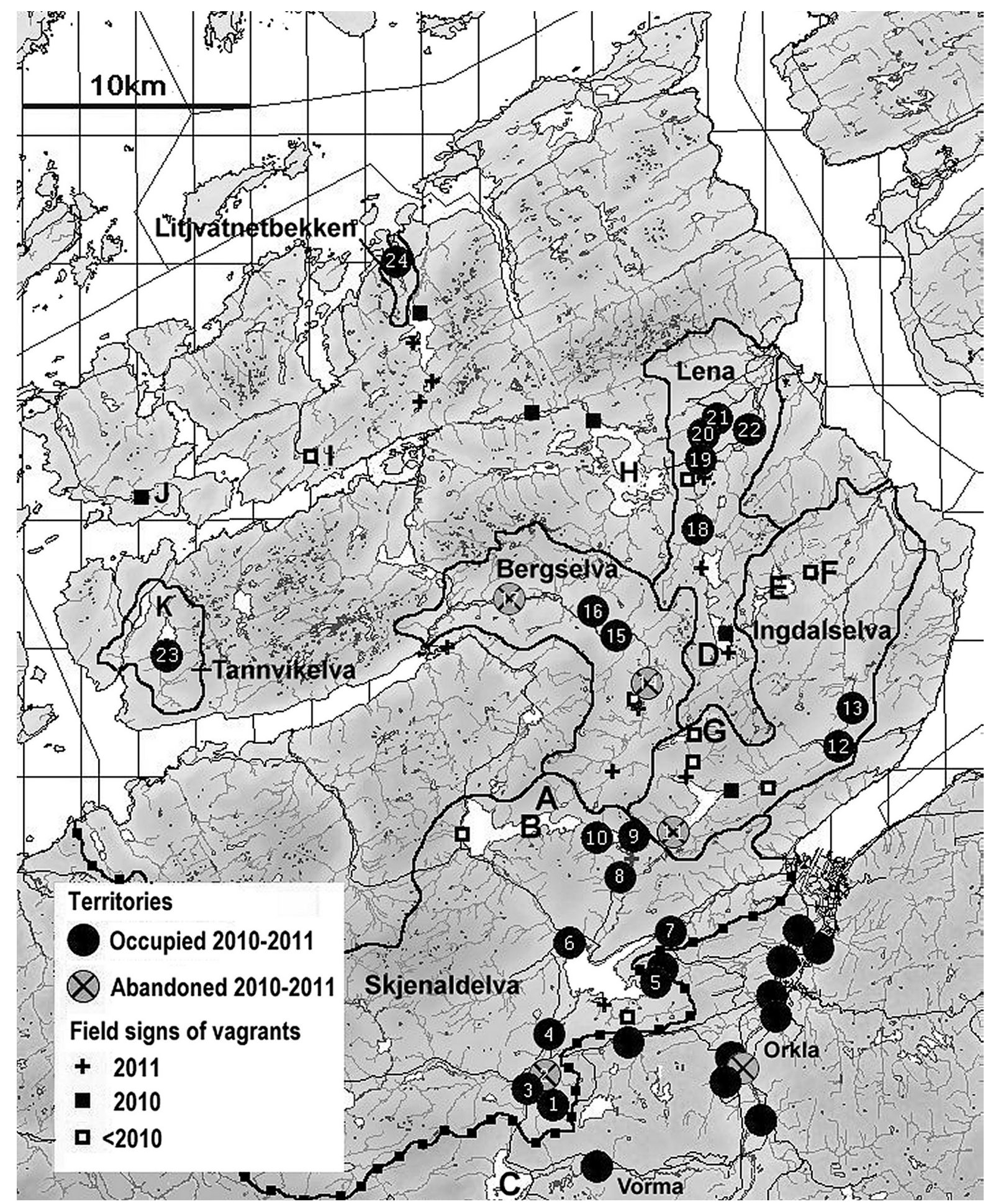

Figure 4. Study area, showing the location of active and abandoned beaver territories in 2010-2011 and of signs of vagrant beavers where no territory is established. The thick black line with squares indicates the land boundary of the study area on the south and west (see text for details), and plain black lines boundaries of watersheds in the study area containing beaver territories. These watersheds are named. The position of the lower Orkla river and its Vorma tributary are indicated. Territory symbols are centred on the active den, or apparent most recently active den for abandoned sites. Numbers for territories are as in Table 1. Territories shown without numbers are outside the study area, on the Orkla river watershed. Letters indicate the position of places mentioned in the text. "Field signs" for vagrants 2010 and 2011 were judged to have been made in the period late April-July of the year named, for $<2010$ at any time before 2010. Data for the Orkla watershed: Bonvik \& Rønning 2006 and pers. obs. Map: ArcView/ESRI 


\section{7 (Lindsetmo 1974).}

An isolated population of beavers on the main Orkla river as far away as the ca. $20 \mathrm{~km}$ long section between Ulsberg and Voll in Rennebu kommune (Figure 1), first reported at Eggjabakken in 1933, was attributed to spread from the 1926 reintroduction (Olstad 1937). An occupied lodge in this section was recorded in 1933-34; beavers were seen in 1938 and 1940, when another lodge was built at Brattset at the Orkla/Ea confluence (UTM NQ639556). Beavers were noted as present at or near this site in 1941 (Skogdirektøren 1943), but had gone by 1945 (Torp 2000a). 1945-50 beavers were reported on the same section at Flå; and again from 1952-63 (Torp 2000a). In 1961 an entire lodge, apparently not from Flå, was washed downstream from this river section, and 'vagrant' signs were recorded in the Orkla from 1960-65 (Myrberget 1967, 1969). Beavers were also resident on the upper Svorka, a tributary of the Orkla, in the late 1940s (Torp 2000a,b) at Svahyllan (ca. UTM NQ927457), which can be reached from the Ulsberg-Voll section either by swimming down the main Orkla and up the Svorka, or (more probably) by a short overland crossing from side streams of the section.

Myrberget (1977) considered that the species was extinct throughout Sør-Trøndelag in 1965; however, beavers reappeared in the Ulsberg-Voll section of the Orkla from 1974 (signs considered from a vagrant animal, Myrberget 1977). From the late 1970s they were recorded as again established at Brattset and at Voll (Torp 2000a; Bonvik \& Rønning 2006), though as late as 1991 Eklid \& Grindal (1991) considered there to be only one occupied territory on the Orkla, at Voll. Continuity from the 1970s with the earlier population must be strongly suspected, the alternative explanation being a repeat long-distance recolonisation from the study area, this time involving two watershed crossings or a long movement through Orkdalsfjorden before entering the Orkla. Dispersal into the Orkla from the Glomma watershed to the east (recolonised NE of Røros from Swedish watersheds from the later 1960s (Hartman 1995), and spreading throughout the Glomma 19751985 (Bevanger 1995)), is also possible from the 1970s and later. The species recolonised the main Orkla river away from the Ulsberg-Voll section only from the later 1990s, and is still at relatively low densities on tributaries (see Torp 2000a, 2000b, and Bonvik \& Rønning 2006 for a review of historical data).

The distribution of beavers in the field area in 2010-11 is shown in Figure 4 , and each currently or formerly established territory briefly described in Table 1 .

There were 24 beaver territories, 20 currently active and 4 sites which had formerly been the site of territories but were now abandoned. In 10 of the active territories, the main den was a burrow; in 6 a lodge, in 3 burrow-lodges (which begin as burrows but end as lodges), and in one case a lodge-burrow (which begins as a lodge but ends as a burrow). Two of these occupied territories $(7 \& 12)$ had been noted as abandoned in 2010 but were reoccupied by 2011. One other territory (9) was certainly new, established in 2011. Two of the abandoned sites clearly contained insufficient suitable habitat to sustain beavers for more than a few years (site 2 is a small stream in forest bog habitat with at time of colonisation only scattered and small trees; and site 17 is a single pool in a river with long stretches of high gradient rapids above and below the site). All four showed evidence of local depletion of deciduous trees by beavers.

Eighteen of the active sites, and all of the abandoned sites, were located on just four watersheds. Two other watersheds had a single established territory each, and there were signs of non-resident beaver presence on four other watersheds where no territorial groups were established. Fresh beaver signs, indicating the presence of nonresident beavers during the period of the survey, were noted for 3 of these watersheds in 2010; fresh signs of presence were noted for one of these watersheds in 2011 as well. Signs in the remaining watershed all dated from before 2010 .

All of the watersheds on which nonresident beaver activity was noted had suitable habitat patches for at least one, and as many as six or more viable beaver territories (site H, Figure 4: Øyangsvatnet lake and the river system into which it drains). Many other watersheds on which no beaver presence was detected also contained suitable habitat of sufficient extent for one or more beaver territories.

\section{DISCUSSION}

Beavers are at an intermediate stage in their recolonisation of the study area, and further spread can be anticipated in future. Assuming an average group size of 3.9 (Rosell \& Parker 1995; Rosell et al. 2005), the results suggest a current territoriallyresident population of about 80 individuals, plus a number of nonterritorial dispersing individuals in any year.

Although it is now 43 years since reintroduction to Ingdalselva, beaver are only securely established on that and three other watersheds (Bergselva, Skjenaldelva, Lena). On those watersheds most or all of the good-quality habitat patches are occupied, with clearly marginal sites such as $1,2,7, \& 15$ either in use or now abandoned. Most stream stretches on these watersheds are too steep to occupy (see Methods), and many lake shorelines too exposed to wave action to build lodges. In both cases many stretches are unsuitably vegetated with pure conifer stands. Some sites on these watersheds are known to have had repeated cycles of occupation and abandonment; at site 13 at least 3 separate periods of occupation are known. This is typical of relatively marginal sites in mature populations, where beavers consume broadleaf woody resources more quickly than they can regenerate and, following resource exhaustion and abandonment, can only reoccupy the site after a period of regeneration. Single groups are relatively recently established on two more watersheds, and these have both selected high quality habitat patches. This pattern is in accordance with other studies, which show a pattern of rapid colonization within watersheds, strong selection for the highest 
quality unoccupied habitat available, progressive lowering of the quality of habitat on which settlement occurs as a watershed population grows, and a strong barrier effect of watershed divides on dispersal (Hartman 1994, 1995; Fustec et al. 2001; John et al. 2010; Halley et al. 2002 for review). Beavers are known to have colonised site 2, on Skjenaldelva watershed, within 5 years of the initial release on Ingdalselva. However, the crossing from the early-occupied site 11 into Skjenaldelva near current site 9 , is a low col bottomed by forest bog, with site 11's home stream separated by only a few hundred metres from Skjenaldelva headwaters.

While the beavers on the Ulsberg-Voll section of the Orkla (Figure 1) have been attributed to spread from the 1928 Åmotstjønna reintroduction (1930s-1960s population), and again from the 1967-68 Ingdalselva reintroduction (1974- population), this section of the river, about $85 \mathrm{~km}$ from Amotstjonna assuming spread via the Vorma tributary of the Orkla (the shortest route by water, with a relatively short land crossing between watersheds), is for most of its length a remote and heavily wooded, steep-sided gorge rising $200 \mathrm{~m}$ directly from the riverbank, very difficult of access to humans. It emerges into a flatter valley bottom of mixed woodland and fields at Flå, $8 \mathrm{~km}$ above Voll. The records mainly relate to more accessible points on this stretch. The topography and vegetation in the gorge is such that beavers could live in burrows with few obvious signs of presence, so it is possible these beavers may have been descendants of a remnant of the original population which survived at this location. Colonising beavers usually either occupy sites adjacent to existing territories, or make longer distance dispersals to patches of high quality habitat some distance from existing territories (Fustec et al. 2001; John et al. 2010; Halley \& Rosell 2002 for review). The pattern in Ulsberg-Voll from the 1930s-1970s is consistent with shortdistance colonisations from a refuge in the gorge, which is then noted by the human population of the wider-bottomed river valley below. Beavers were known to be living in the gorge for 'many years' in the mid-20th century (Voll pers. comm. in Torp, 2000), and do so today. The 1933 occupied lodge would require a colonisation from Åmotstjønna/Våvatnet over at least $85 \mathrm{~km}$ within 5 years (as the reintroduced pair did not breed in the first year, and dispersal occurs at the earliest at one year old, i.e. in 1928), from a reintroduction stock of at most six animals on a different watershed. Once in the Orkla, colonising animals would have to pass upstream through successive $14 \mathrm{~km}$, $7.5 \mathrm{~km}$ and $5 \mathrm{~km}$ river sections too steep and fast for beaver occupation, en route. Both a male and a female would have to make the trip separately, as dispersal occurs as individuals. The furthest known colonisation distance previously recorded is of $80 \mathrm{~km}$, on the Loire, but this did not involve a watershed crossing and was on a river on which beavers were already firmly established (Halley \& Rosell 2002; Fustec et al 2001). Conversely, persistence of a population which went unrecorded in print for over a century seems unlikely, even in so remote a location. Genetic studies would be useful to determine the origins of this population.

Whatever the origins of the Orkla population, the population there was at low numbers and of very restricted distribution until the 1990s. The present population in the field area therefore appears to be mainly descended from the 5 animals released in 1968-9 on the Ingdalselva, probably supplemented since the later 1990s by immigrants from the Orkla watershed. The part of the field area within Orkdal kommune, as well as the middle and lower course of the Orkla and its major tributaries, were surveyed in 2005 by Bonvik \& Rønning (2006).

The study area contains many small watersheds; dispersal between them requires either crossing land, or swimming for some distance through salt water and then ascending the terminal stretch of the river/stream, which is in most cases much too steep and rapid to swim through for some distance beginning either at, or very close to, the point where it reaches the fjord/sea. The pattern of distribution suggests that land crossings may have been the way in which the three main occupied watersheds (Skjenaldelva, Bergelva, Lena) to which beavers were not directly reintroduced were colonised. All could have been reached from the headwaters of the Ingdalselva system, and Lena-Bergelva and Skjenaldelva-Bergelva from each other, by single, short overland crossings between side streams in gently sloping cols between hills. Site 23 was most likely colonised by animals dispersing from Bergselva and through the fjord into which it drains, which would involve swimming through ca. $15 \mathrm{~km}$ of sheltered salt water. The watershed at site 23 is unusual for the area in being of relatively low gradient where it reaches the fjord; while most stretches are nevertheless too steep for colonisation, only one short stretch some way inland is so steep that beavers would have to leave the water and walk (site K, Figure 4; territory 23 lies upstream of this stretch). Site 24 is difficult to interpret, colonisation involving either crossing three watershed divides, swimming for an extended distance through salt water, or a combination of the two. Litjvatnetbekken is a stream which is much too steep to swim through in its final $2 \mathrm{~km}$ to the sea, so if the animals ascended that way they must have walked in or beside the stream bed.

In 1970 a beaver was found fatally injured (shot) on the coast of Trondheimsfjord at Trolla near Trondheim (Adresseavisen newspaper 12 August 1970) ${ }^{4}$. By far the nearest population was the new reintroduction at Ingdalselva. Ingdalselva is $21 \mathrm{~km}$ away through salt water; $26 \mathrm{~km}$ assuming following the coastline, including a $5 \mathrm{~km}$ crossing of the mouth of Orkangerfjord (there is no plausible freshwater route).

There is extensive movement of non-territorial beavers both within colonised watersheds and in watersheds without established territories. Signs of beaver presence are frequently found at sites which would be suitable for settlement, implying that single individuals do not settle permanently at a site unless

4. The newspaper photograph shows an adult size animal. This may have been the third individual of the 1969 Ingdalselva release. 


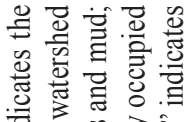

흘

s

政

突.

5.

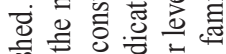

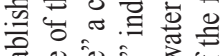

敋

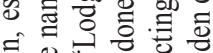

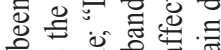

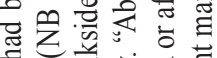

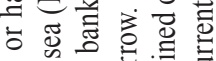

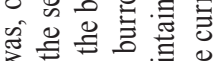
年

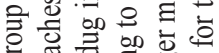

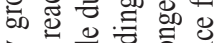

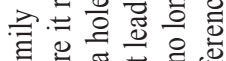

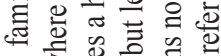
돈

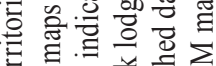

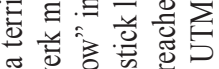
क

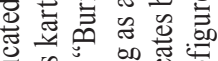

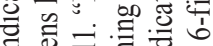

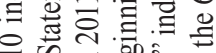

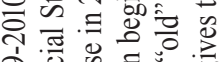

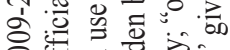

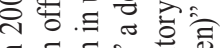

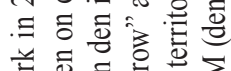

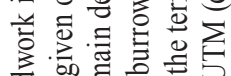

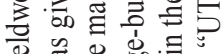

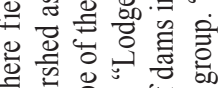
要

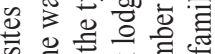

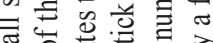

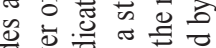
年

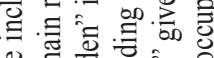
政 这

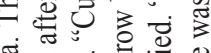

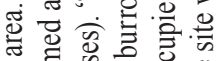

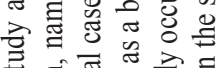

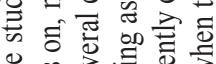

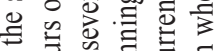

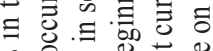
象.

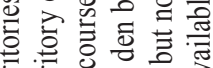

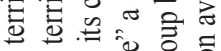

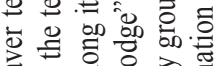

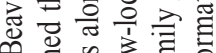

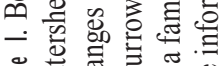

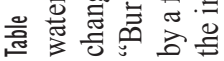

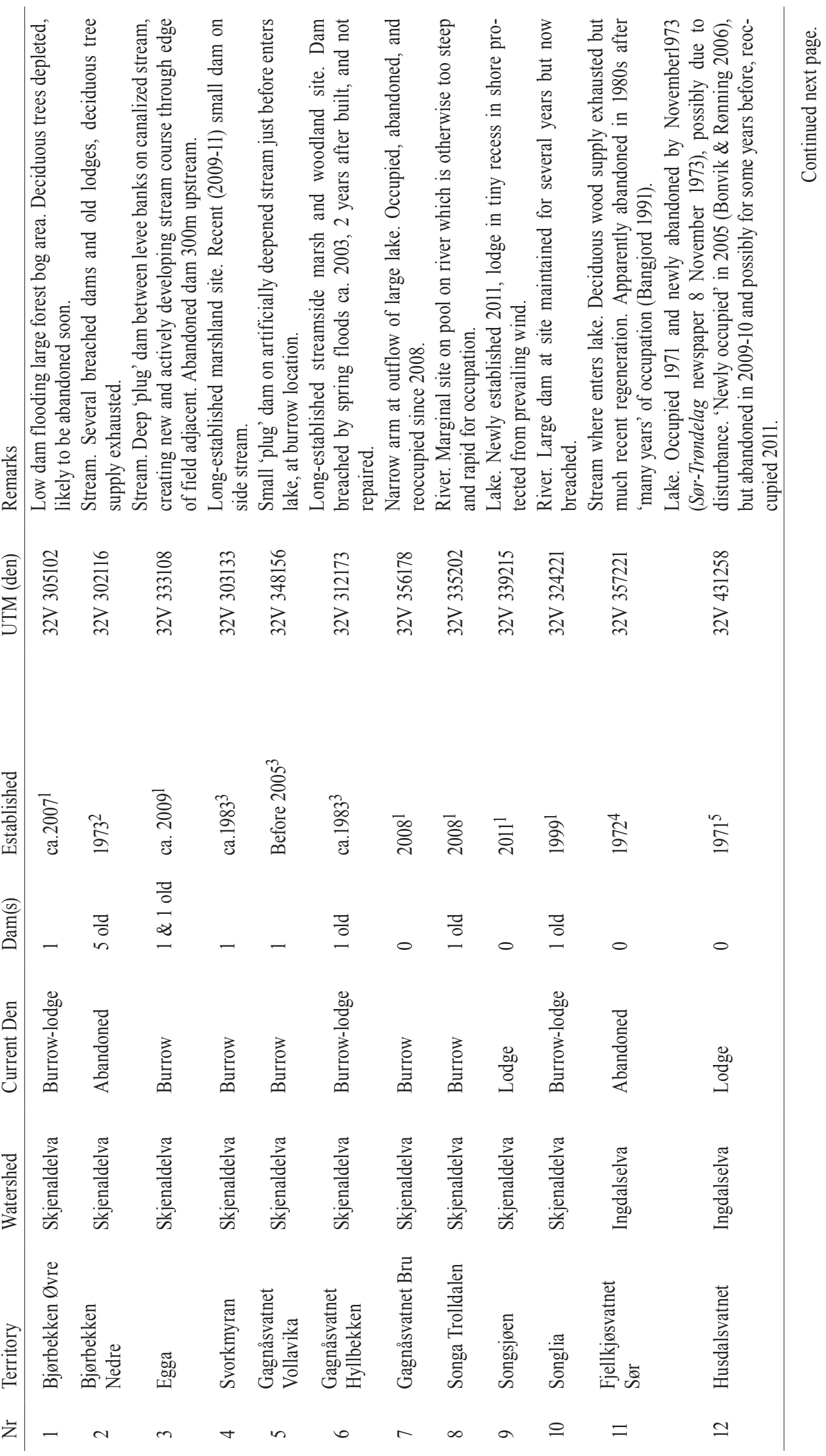




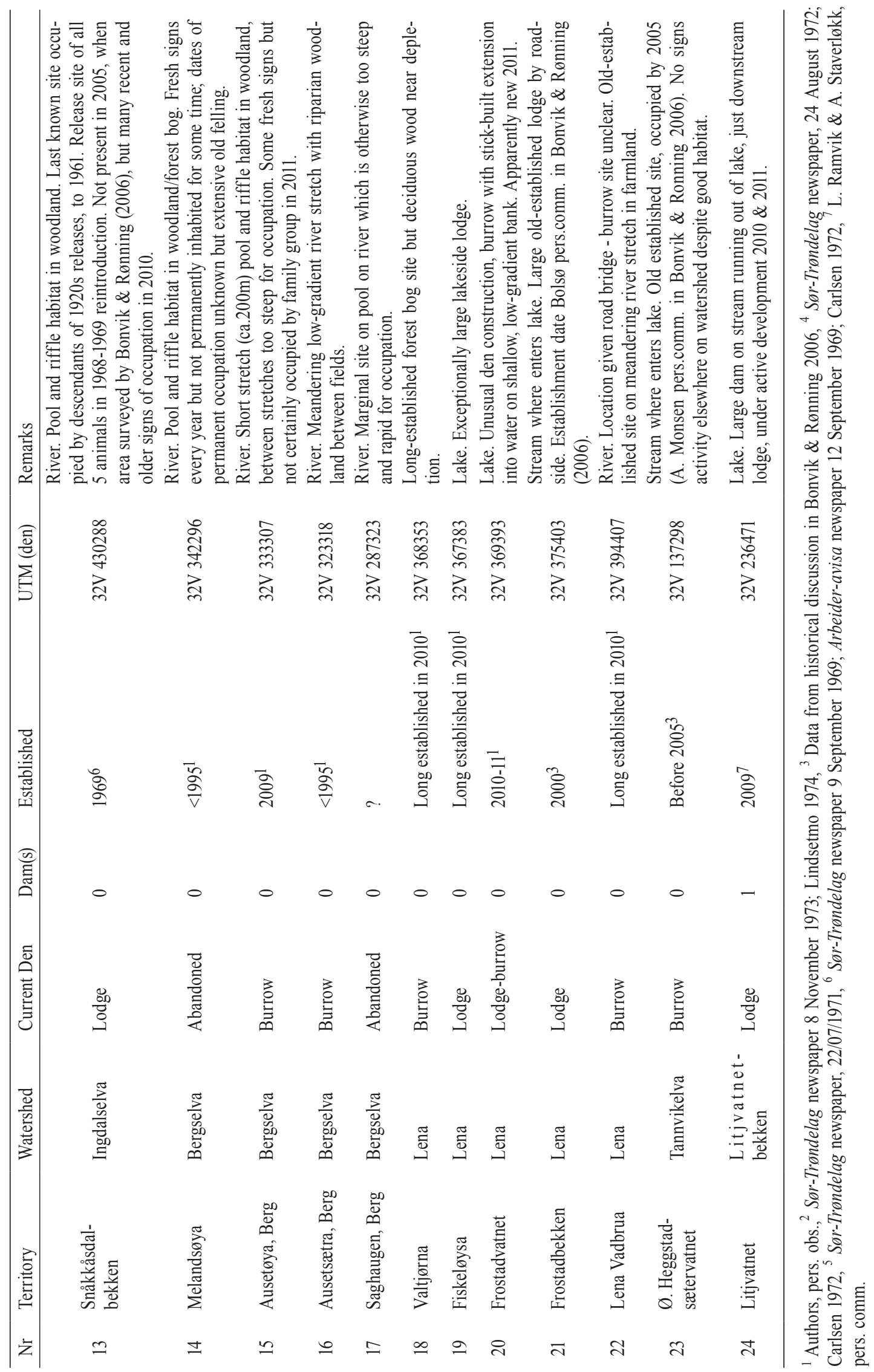


they can find a mate. This may explain the longer distance colonisations of sites 23 and 24 , as in part being due to fortuitous meetings of opposite-sex wandering individuals. Almost nothing is known of dispersal behaviour, however. Radio telemetry using GPS tags would be very useful to elucidate this area if the formidable practical problems of capturing dispersing or pre-dispersing individuals, and keeping the tags on them for a long enough period, can be solved. In at least two cases where vagrants were present on short streams connecting directly to a fjord (sites I \& J, Figure 4), movements of some distance through salt water in fjords followed by ascending fjord-wall stream stretches much too steep to swim through, appear the only plausible line of approach.

It is intended that the further pattern of recolonisation of the area will be monitored from the baseline established here, in succeeding years. In particular we hope to obtain better information on the strength of watershed crossings as barriers to dispersion, and whether salt water acts as a barrier to, or facilitates, dispersion between watersheds.

For management of populations, the data suggest that in similar dissected landscapes beavers can be limited as an established breeding species to selected watersheds if desired, provided that occasional colonising pairs on new watersheds are removed before they have the chance to breed. The activity required can be measured in interventions per decade. Conversely, if a wide distribution is desired, a strategy of multiple releases to different watersheds is indicated. The extensive signs of vagrant individuals suggest that where beavers are already established, beaver movements between watersheds will be sufficient to maintain gene flow without further translocations.

\section{ACKNOWLEDGMENTS}

The beaver reintroduction of 1968-69, which founded the study population at exactly known dates and site, was planned and carried out by Karl H. Brox, Erik M. Carlsen, Einar M. Møller, Kåre Klebo and Einar Hjorthol (Figure 5)

Our sincere thanks are due to Karl H. Brox, who made available considerable material on the history of the 196869 reintroduction as well as private correspondence on the reintroduction with E.M. Carlsen and others. Johan Andøl and Holgeir Oppdal provided supplementary information. Livar Ramvik and Arnstein Staverløkk reported new establishments and old and new signs of vagrant beaver. Bonvik \& Rønning's 2006 investigation of beavers on the Orkla was invaluable for information on the Orkla population, and on the status of beavers in the Orkdal kommune section of the study area in 2005. This work and Torp's 2000 reports on beavers in Meldal and Rennebu were similarly invaluable for the history of beavers on the Orkla. Kjetil Bevanger provided a fascinating archive of newspaper clippings on beaver in Norway 1959-74 saved from the Department of Nature Management dustbin, which provided

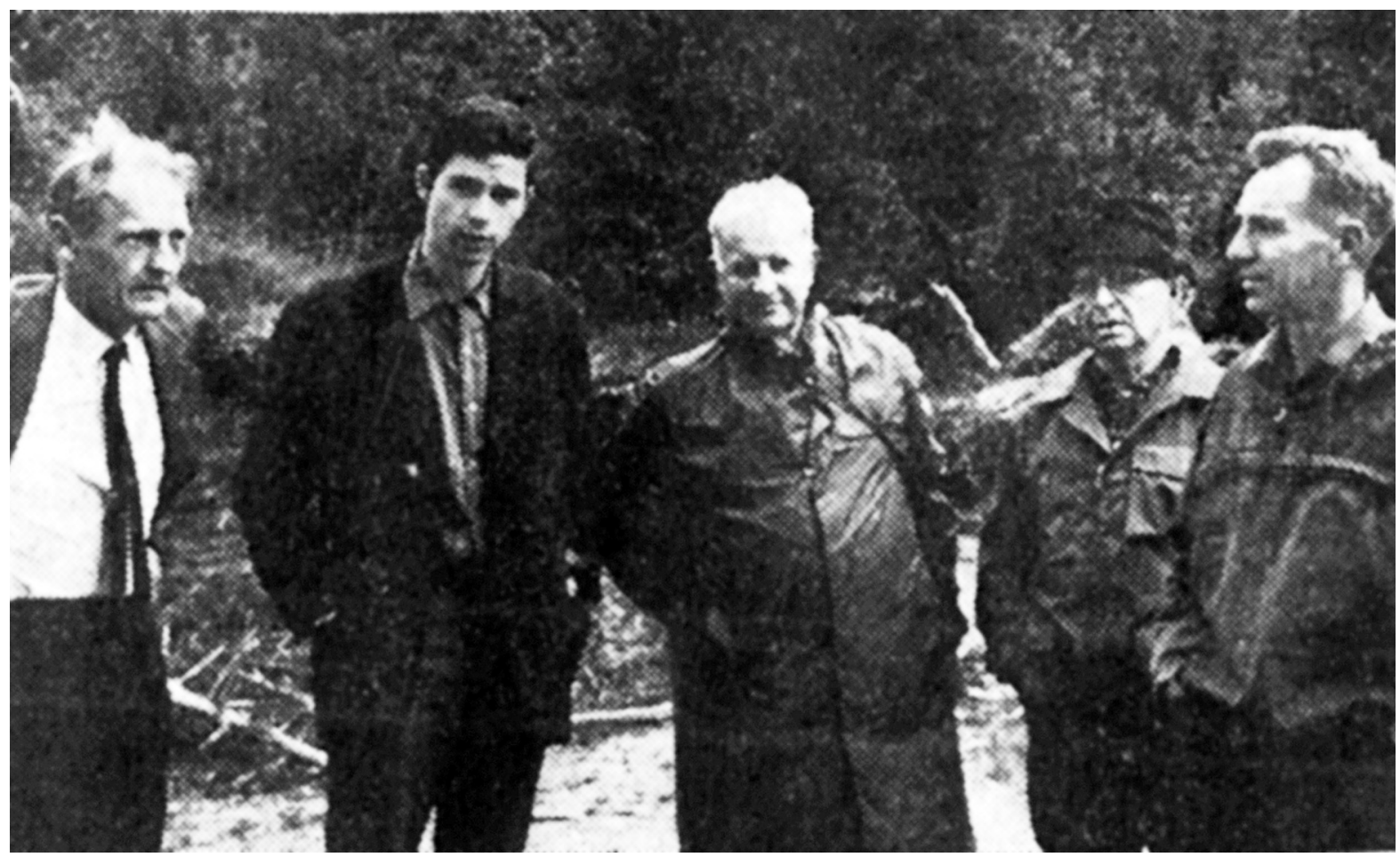

Figure 5. Founders of the study population at the release of the first pair, Snåkkåsdalbekken, $1^{\text {st }}$ September 1968. Left-right: Kåre Klebo (forest manager); Karl H. Brox; Emil M. Carlsen; Einar Møller (leader, S Trøndelag Nature Protection Society); Einar Hjorthol (head of Sør-Trøndelag Forest Authority). Photo: Orkla-Posten newspaper, 12 September 1968. 
much detail on the early stages of the 1968-69 reintroduction and cleared up some points where later sources conflicted, such as the exact reintroduction site. Two anonymous reviewers provided constructive criticism which significantly improved the paper. Part of the survey in 2010-11 was carried out in the course of work for the EnviPeak programme of the Centre for the Environmental Design of Renewable Energy (CEDREN).

\section{REFERENCES}

Aune O. 1969. Bever observer i Nord-Trøndelag og utsatt i SørTrøndelag (Beaver observed in North Trøndelag and released in South Trøndelag). Fauna 22:61.

Bangjord G. 1991. Viltet i Orkdal kommune (Game in Orkdal kommune). Naturundersøkelser A/S. 1991. 64 p.

Beier P, Barrett RH. 1987. Beaver habitat use and impact in Truckee River Basin, California. J. Wildl. Man. 51:794-799.

Berthelsen JP. 2008. Overvågning af bæver Castor fiber i Danmark 2006 (Monitoring of beaver Castor fiber in Denmark). DMU Work Report nr. 243, Danmarks Miljøundersøgelser, Aarhus Universitet. 44 p.

Bevanger K. 1995. Beverens gjenerobring av Norge (The beaver's reconquest of Norway). In: Natur 1995 (ed. K. Brox), Tapir Forlag, Trondheim, Norway. pp. 1-16.

Bonvik C, Rønning H. 2006. Forvaltningsplan for bever langs Orkla og større sidevassdrag (Management plan for beavers on the Orkla and its larger tributaries). Report, Bonvik Utmarksanalyse \& Rønning Utmarkstjenester, Orkanger. 43p.

Carlsen M. 1972. Bever i Meråker (The beaver in Meråker). Adresseavisen 23/11/1972

Collett R. 1898. Bæveren i Norge, dens utbredelse og levemaade (The beaver in Norway, its distribution and lifestyle). Bergen Museums Aarbog for 1897: 1-127.

Direktoratet for naturforvaltning. 2003. Historien om Songli (The history of Songli). Direktoratet for naturforvaltning notat 2003-4.

Eklid R, Grendal M. 1991. Viltet i Rennebu kommune (Game in Rennebu kommune). Rennebu kommune, 54p.

Elmeros M, Maden AB, Berthelsen JP. 2003. Monitoring of reintroduced beavers (Castor fiber) in Denmark. Lutra 46: 153-162.

Fustec J, Lode T, Le Jacques D, Cormier JP. 2001. Colonization, riparian habitat selection, and home range size in a reintroduced population of European beavers in the Loire. Freshwater Biology 46: 1361-1371.

Halley DJ. 2011. Sourcing Eurasian beaver Castor fiber stock for reintroductions in Great Britain and Western Europe. Mammal Review 41: 40-53

Halley DJ, Rosell F. 2002. The beaver's reconquest of Eurasia: Status, population development, and management of a conservation success. Mammal Review 32: 153-178.

Hartman G. 1994. Long-term population development of a reintroduced population in Sweden. Conservation Biology 8: 713-717.

Hartman G. 1995. Patterns of spread of a reintroduced beaver Castor fiber population in Sweden. Wildlife Biology 1: 97-103.

Hartman G. 1996. Habitat selection by beavers recolonizing a boreal landscape. Journal of Zoology Lond. 240: 317-325.

Hartman G, Törnlöv S. 2006. Influence of watercourse depth and width on damming behavior by Eurasian beaver (Castor fiber). Journal of Zoology 268: 127-131.

Howard RJ, Larson JS. 1985. A stream habitat classification system for beaver. The Journal of Wildlife Management 49:19-25.

John F, Baker S, Kostkan V. 2010. Habitat selection in an expanding beaver (Castor fiber) population in central and upper Morava River Basin. European Journal of Wildlife Research 56:663-671. DOI 10.1007/s10344-009-0361-5.

Lindsetmo O. 1974. Beveren tilbake i Orkdalsskogene (The beaver is back in the Orkdal forests). Adresseavisen 19 January 1974.

Lund HM-K. 1959. Om beveren i Norge (On the beaver in Norway). Skogeieren 1959: 61-63.

Myrberget S. 1967. Den norske bestand av bever, Castor fiber (The Norwegian population of beaver). Meddelser fra Statens viltundersøkelser. 2. serie, nr. 26. Orkanger. 38p + appendices.

Myrberget S. 1969. Beveren og viltstellet (The beaver and game management). Jakt, fisk \& friluftslivet 1969, 14-16.

Myrberget S. 1977. Beverens utbredelse i Norge omkring 1975 (The beaver's distribution in Norway ca. 1975). Nordisk beversymposium 1975. Report 26, Skogshögskolan, institusjonen for skogzoologi, 13-18.

Møller, EM. 1967. Bever-slipp på Songli lørdag på minister Thams 100-års dag (Beaver release at Songli on Saturday on Minister Thams 100th birthday). Adresseavisen 8 September 1967.

Møller EM. 1970. Orkdalsbeverne lever i beste velgående (The Orkdal beavers are alive and thriving). Adresseavisen 2 November 1970

Nyssen J, Pontzeele J, Billi P. 2011. Effect of beaver dams on the hydrology of small mountain streams: example from the Chevral in the Ourthe Orientale basin, Ardennes, Belgium. Journal of Hydrology 402: 92-102. doi:10.1016/j.jhydrol.2011.03.008

Olstad O. 1937. Beverns (Castor fiber) utbredelse i Norge (The beaver's distribution in Norway). Nytt Magagasin for Naturvidenskapene 77: 217-273.

Pedersen JA. 1967. Bever i Orkdal, Sør-Trondelag (Beaver in Orkdal, South Trøndelag). Fauna 20:109-110.

Rosell F, Bozsér O, Collen P, Parker H. 2005. Ecological impact of beavers Castor fiber and Castor canadensis and their ability to modify ecosystems. Mammal Review 35: 248-276.

Rosell F, Parker H. 1995. Beaver management: present practice and Norway's future needs. Bø, Norway, 137p.

Rosell F, Pedersen VK. 1999: Bever (The beaver). Landbruksforlaget.

Schulte R. 1989. Dambuilding of European beavers and its importance for the colonization of fast running streams in the Eifel-mountains. In: Abstracts. Fifth International Theriological Congress: 313. Rome: Nage Snc.

Sjöberg G, Ball JP. 2011. Restoring the European beaver: 50 years of experience. Pensoft, Sofia-Moscow.

Skogdirektøren (Forest Director). 1943. Årsmelding for det norske skogvesen for 1941 (Annual report for the Norwegian Forest Authority, 1941). Oslo, 85 p.

Slough BG, Sadleir RMFS. 1977. A land capability classification for beavers. Canadian Journal of Zoology 55:1324-1355.

Torp E. 2000a. Beverbestanden i Meldal kommune høsten 1999 (The beaver population in Meldal kommune in autumn 1999). Report, Meldal kommune. 22 p. 
Torp E. 2000b. Beverbestanden i Rennebu kommune høsten 1999 (The beaver population in Rennebu kommune in autumn 1999). Report, Rennebu kommune. $23 \mathrm{p}$.

Zurowski W. 1992. Building activity of beavers. Acta Theriologica 37: 403-411.

Editorial responsibility: Åslaug Viken.

This article is open-access and distributed under the terms of the Creative Commons Attribution-Noncommercial 3.0 Unported License (http://creativecommons.org/licenses/by-nc/3.0/). This permits all non-commercial use, distribution, and reproduction in any medium, provided the original work is properly cited. 